\title{
Types of Entrepreneurs in Small Hotels in Slovenia
}

\author{
Saša Zupan Korže \\ Vanadis d.o.o., Slovenia \\ sasa.zupan@vanadis.si \\ Sonja Sibila Lebe \\ University of Maribor, Faculty of Economics and Business, Slovenia \\ sonjasibila.lebe@guest.arnes.si
}

Entrepreneurship is associated mostly with establishing of new ventures, mainly of small and medium size companies (SMEs). It is linked closely with the entrepreneur: The key person who plays the key role in the entrepreneurial process. In theory, different criteria have been used in the past to identify the typology of entrepreneurs, e.g. the period of entrepreneurial activity, their economic or non-economic goals, etc. (Dunkelberg, Moore, Scott, \& Stull, 2013; Dincer, Yildirim \& Dil, 2011; Hisrich, Peters, \& Shepherd, 2010; Glas, 2002; Smith \& Miner, 1983). The main purpose of this paper is (a) To the identify typology of entrepreneurs in Small Hotels (sH) in Slovenia and (b) To compare the results with findings of similar studies in existing literature (Page \& Connell, 2014; Lee-Ross \& Lashley, 2009). Empirical research was conducted in Slovenia in 2014 and 2015. The data were collected from SH entrepreneurs and SH Directors (a) By conducting 62 semi-structured interviews and (b) By analysing 44 questionnaires filled in by $\mathrm{sH}$ entrepreneurs. We analysed data from interviews using qualitative methods (interpretation, comparison, grouping, quantification). The numerical data were processed and analysed by using multiple statistical tools (factor analysis, hierarchical classification, Ward's method). sH entrepreneurs in Slovenia share certain typology characteristics with their colleagues in the hospitality business abroad; however, there are less lifestyle entrepreneurs in the Slovene hospitality business than expected (due to comparison with findings in existing literature). This is the first research of entrepreneurial typology in the hospitality business in Slovenia. It offers a clear insight into certain business orientations of hospitality entrepreneurs and, consequently, gives some explanation about tourism entrepreneurship in Slovenia.

Keywords: entrepreneurship in hospitality, TSMEs (tourism small and medium enterprises), small hotels, entrepreneurs

https://doi.org/10.26493/2335-4194.10.129-140

\section{Introduction}

Entrepreneurship in the Hospitality Sector

In academic literature, political documents, and in media, there are different opinions and several definitions of entrepreneurship and entrepreneurs. The reason is the multidisciplinary nature of both phenom- ena (Ateljević \& Li, 2009; Lee-Ross \& Lashley, 2009). Rebernik (2008, p. 30) relates this problem to the 'slippery nature' of both terms. Global Entrepreneurship Monitor, for example, considers entrepreneurship as 'any attempt at new business or new venture creation, such as self-employment, a new business organisation, 
or the expansion of an existing business, by an individual, a team of individuals, or an established business' (Global Entrepreneurship Monitor, 2015, p. 9).

The majority of other researchers focused on some of this phenomenon's features: They tackle starting and managing certain business activities (operations), certain resources/capital, or business uncertainty and risks (Cerović, 2010). The basis of entrepreneurship lies in: Dynamics, quest for success, uncertainty, adventure, fearlessness, motivation, ethics, and determination. All these characteristics are related to the person who participates in these activities - to the entrepreneur.

In business science, entrepreneurs and entrepreneurship are often connected to the creation of new ventures, mainly smes. Entrepreneurial activity creates business ventures and is actualised through them (Cerović, 2010); business ventures are, therefore, understood as a tool for the fulfilment of entrepreneurs' visions and goals.

Historically, tourism depends on individuals who found business opportunities in accommodation, food services and tourism, and who transformed their ideas into businesses (Cerović, 2010). Successful businesses in the accommodation and food services sectors have always depended largely on entrepreneurs and their visions, their entrepreneurial capacity and their ability to find and to pursue business opportunities (Page \& Connell, 2014). They target the segment of guests which cannot be satisfied with the services offered by mass tourism (Lebe \& Milfelner, 2006).

Entrepreneurship in Small and Medium sized Enterprises in tourism and hospitality (TSME) gained in importance only in the last decade of the previous century (Page \& Connell, 2014). There are two reasons for that. First, due to the increased general attention regarding entrepreneurship, and second, due to the increased number of TSMEs belonging to the sector of hospitality and tourism. The increase in the number of TSMES is due to (a) Relatively low entrance cost into the activity, (b) Pursuing opportunities for setting up lifestyle businesses and (c) The attractive nature of these service processes (Lee-Ross \& Lashley, 2009).

Some authors believe that individuals have abilities and a free will to decide about their entrepreneurial career (Getz, Carlsen, \& Morrison, 2004; Kuratko \& Hodgetts, 1998). Their decisions are influenced by a set of complex and multidimensional circumstances, which stem from contemporary individuals, society and economy. These circumstances influence the entrepreneurial behaviour cues (Getz et al., 2004). Entrepreneurship should, thus, be considered by taking into account personal elements of individuals and the social environment in which they operate (Lee-Ross \& Lashley, 2009). In the U A, for example, entrepreneurs have the status of 'modern heroes.' In Europe, however, where security, stability and orderly relationships are valued higher than in the U A, it is difficult to succeed in entrepreneurial activities (Glas, 2000).

Morrison (2001) and Getz et al. (2004) see the decision for an entrepreneurial career as a consequence of the individual's personal characteristics, his/her environment, his/her personal goals, of the business environment, and of the existence of a viable business idea. The authors advocate that entrepreneurs do not appear out of nowhere: The entrepreneurial process is born from appropriate social and economic systems that offer a friendly environment to the future entrepreneurs.

The theory describes several types of entrepreneurs - yet they can be clustered into one of the following main five groups: (a) Entrepreneurs motivated by necessity or opportunity (Minarcine \& Shaw, 2016; Global Entrepreneurship Monitor, 2015; Rebernik et al., 2015; Amit \& Muller, 2013; Hisrich et al., 2010), (b) Owner-managers or owner-supervisors (Velu \& Jacob, 2016; Lee-Ross \& Lashley, 2009; Peltier, Schibrowsky, \& Zhao, 2009); (c) Nascent or established/experienced entrepreneurs (Emami \& Dimov, 2017; Cerović, 2010; Baron \& Ansley, 2006; Rebernik, Tominc, Glas, \& Pšeničny, 2004; Antončič, Hisrich, Petrin, \& Vahčič, 2002); (d) Family or non-family type (Randolf, Li, \& Daspit, 2017; Randerson, Bettinelli, Fayolle, \& Anderson, 2015; Getz \& Nilsson, 2004; Medlik \& Ingram 2000); (e) Business-oriented or lifestyle entrepreneur (Sun \& Xu, 2017; Bredvold \& Skalen, 2016; Presenza, Yucele, \& Camillo; 2015; Lee-Ross \& Lashley, 2009).

The research question in this paper was to explore which types of entrepreneurs prevail in SHS in Slovenia. 


\section{Types of Entrepreneurs}

We can group entrepreneurs into different types according to the fact whether they have become entrepreneurs because they were forced to do it - in this case we speak about 'push factors' and entrepreneurs 'motivated by necessity' - or persons who wished to become entrepreneurs; here, we can talk about 'pull factors' and about entrepreneurs 'motivated by opportunity' (Rebernik et al., 2015; Amit \& Muller, 2013; Antončič et al., 2002). Push factors triggered by necessity/need might be, for example, unacceptable circumstances of the person's present job, or even job loss etc., whereas pull factors as opportunities represent certain advantages, e.g. work from home, being one's own boss, attaining an attractive lifestyle etc. (Minarcine \& Shaw, 2016; Hisrich et al., 2010; Lee-Ross \& Lashley, 2009). The European Union's research on entrepreneurship ('Entrepreneurship in the EU and beyond,' 2010) showed that $55 \%$ of respondents entered the entrepreneurship due to an opportunity, and only $28 \%$ out of necessity. In the USA and Switzerland, the share of entrepreneurs because of opportunity exceeds $60 \%$. In China and Japan, one half of individuals become entrepreneurs out of necessity. In Slovenia, entrepreneurship triggered by an opportunity had a higher share in the past, yet the share of entrepreneurs from necessity has been increasing since 2012 (Rebernik et al., 2015).

Once they have become entrepreneurs, most people get a new life experience, which is often associated with their desire to control their own work activity, as well as its scope (Page \& Connell, 2014). It is, thus, up to the entrepreneur to decide which duties to take over. The decision is influenced by the nature of the activity, the scope of business activities and the entrepreneur's own preferences. They might decide to take:

- Only the ownership function, in which they supervise the enterprise;

- The ownership and the management functions in this way, they supervise and manage the company completely;

- The ownership and the management functions and, additionally. the role of implementer.

According to the above-mentioned criteria, we dif- ferentiate between the entrepreneur 'owner' and the entrepreneur 'owner-manager.' If entrepreneurs own the company, they ensure and combine financial and other resources in order to accomplish their business opportunity; if they are managers at the same time, they also manage the company. Most frequently, we speak about the administrative-managerial function - 'owner-manager' (Velu \& Jacob, 2016; Lee-Ross \& Lashley, 2009). In some types of entrepreneurship - if the entrepreneur is the owner and, at the same time, the only employee - the entrepreneurs try to act as independently as possible. On the company level, they carry out all three functions: They are supervisors, managers, and take care of the implementation at the same time.

Entrepreneurship is not a profession that could be simply learned. It is a mix of an individual's competencies based on their personality traits (which are, to some extent, innate) and different skills. The ability to become an entrepreneur thus represents a combination of natural gifts, personality traits, as well as the result of learning and experience (Cerović, 2010). In other words, entrepreneurs should possess not only talent, but also knowledge and different skills in order to be capable of leading their companies successfully (Antončič et al., 2002). Thus, some authors differentiate between nascent entrepreneurs and established/experienced ones by translating the length of business activities into entrepreneurs' characteristics (Emami \& Dimov, 2017; Cerović, 2010; Baron \& Ansley, 2006). During the nascent phase, entrepreneurs are described as having plenty of ideas and a lot of energy; they are fast in making decisions, and ready to take considerable risks in order to realise their entrepreneurial ideas. During the next phases of business operations, they replace their hasty decisions and their willingness to take risks with more thoughtful decisions, and adopt a much more conservative attitude towards taking risks. Established entrepreneurs are, thus, more realistic in assessing conditions, and more cautious in making decisions than new/nascent entrepreneurs. The latter acquire entrepreneurial skills and the environment gradually, which makes their expectations lower and 'bring them back to earth' (Rebernik et al., 2004). 
Even business conditions (e.g. volume of the loan, market share, reputation etc.), vary significantly between TSMES where entrepreneurs have just started the business from those that are present on the tourism market already for more years. In the first case, business conditions are much tougher than in already established businesses that have acquired certain competencies through the 'learning by doing' principle. Furthermore, the entrepreneurs' enthusiasm towards work changes over the years.

For a successful business venture, it is important that the entrepreneur knows the industry in which his/her business idea will be realised (Tajnikar, 1997). In addition, they should be familiar with product/service processes, the market and other success factors (Glas, 2002). A large number of entrepreneurs start their business ventures in the field in which they have already operated; often they have noticed a market niche and decided to explore it as a business opportunity (Barringer \& Ireland, 2012). However, only a modest number of entrepreneurs entering the hospitality industry have previous experience in hospitality (e.g. as Hotel Managers or other leadership and/or work experiences in the hospitality sector). In their small companies' research in New Zealand, Hall and Rusher (2004) found out that two-thirds of entrepreneurs in hospitality lacked any entrepreneurial experience before entering the hospitality industry, with only one fourth of them having had previous experience in tourism. It is well-known that setting up businesses in the area of hospitality often lacks previous thorough thinking about the key participating actors.

There are different types of entrepreneurs according to their economic goals. The basic characteristic of business-oriented entrepreneurs is that they are mainly profit motivated. They belong to the group of classical entrepreneurs, who prevail in the majority of industries. The engine of their entrepreneurial activity is profit acquired through capital gains, successful economic entrepreneurial activity and company growth. On the other hand, lifestyle entrepreneurs belong to the group of entrepreneurs for whom non-economic motives prevail over economic ones (Bredvold \& Skalen, 2016; Presenza et al. 2015; Lee-Ross \& Lashley, 2009; Getz \& Nilsson, 2004; Glas, 2002). More than in bene- fits visible as economic earnings and company growth, they are interested in other personal benefits achieved by being entrepreneurs. Their business venture is focused on satisfying primarily personal, and only secondary financial goals (Bredvold \& Skalen, 2016; Presenza et al., 2015; Clarke and Chen, 2007). The majority of entrepreneurs in accommodation and food service activities that manage bars, restaurants, small tourist accommodations, etc. belong to this group. Being lifestyle entrepreneurs, they often 'use their business activities for financing their own lifestyle' (Rebernik et al., 2004, p. 20).

Existing studies show that entrepreneurs in TSMES possess a complex combination of motives and desires that pull them into the activity (Shaw \& Williams, 2004). Hospitality activities are suitable for individuals who seek business opportunities in which they can unite personal and professional life in a way they find appropriate (Getz et al., 2004). This kind of people have a strong aspiration to become owners of hotels, because they believe they might enjoy the life of a hotel owner or get more control over their lives (Lee-Ross \& Lashley, 2009). The group of lifestyle entrepreneurs is, therefore, much larger in hospitality and tourism activities than in other industries. Getz et al. (2004) define lifestyle by values and expectations, which - connected with business activities - the owner-managers specify as 'important for themselves.' In this case, motivation and goals of entrepreneurs are not identical with classical criteria of predominantly financial/economic success of TSMES, like revenue, number of employees, growth, market share etc.

In their research of entrepreneurs in TSMES, Getz and Carlsen (2000) found out that the profitability of TSMES is not important to $70 \%$ of respondents, and that $62 \%$ of respondents do not consider company growth as an important goal. They see the motives for entering the hospitality sector predominantly in (Peters, Frehse, \& Buhalis, 2009):

- Quality of life and their enthusiasm for the place where the activity is carried out (in vivid town centres, beautiful countryside);

- Hospitable nature of the business activity, and

- In agreeing with a moderate income. 
The main feature of family businesses is a combination of ownership and managerial function in one person, or the distribution of these functions among the family members (Randolf et al., 2017; Randerson et al., 2015). The needs and tendencies of owners and their families are put in the forefront; the motives and goals of entrepreneurial activities thus differ considerably from non-family type of entrepreneurship. Family entrepreneurship is related closely with the thinking scheme: Family first, business second (Medlik \& Ingram, 2000). In family businesses, family matters are integrated in all business activities of TSMEs: From sharing responsibilities, or participation of children and grandparents in business activities, up to family inheritance etc. According to Getz et al. (2004), family businesses belong to enterprises which do not prioritise economic goals. The research of Getz and Nilsson (2004) showed that $90 \%$ of family businesses are not motivated by economic reasons. In countryside tourist accommodation (e.g. B \& B, small hotels etc.), such types of entrepreneurship prevail.

\section{Research Methodology (Design and Sample)}

With regard to their key approaches to business operations, $\mathrm{sH}$ entrepreneurs do not differ a lot in their business practices from other entrepreneurs in TSMES. Thus, we transfer a large portion of findings that apply to entrepreneurs in TSMES to entrepreneurs in SHS. Special features, related to their business activities and competencies in the field of hotels, are derived from special features of the hotel business.

We conducted an empirical research in Slovene $\mathrm{SH}$ in 2014 and 2015. Data were collected as part of a comprehensive research on hotel entrepreneurship in the State. We investigated (a) What types of entrepreneurs characterise the $\mathrm{SH}$ business in Slovenia and (b) Whether there were significant differences in typology of entrepreneurs in Slovenia compared to entrepreneurs in TSMES' available literature.

Data from $\mathrm{sH}$ entrepreneurs were collected using the method of semi-structured in-depth interviews and, additionally, by a questionnaire, whereas the data from $\mathrm{sH}$ Directors were collected by interviews only. For our research purpose, we determined an $\mathrm{sH}$ as being a privately owned (entrepreneurial) small tourist accommodation (at least 10 and not more than 50 rooms/units for rental) that offers hotel services. We identified 125 SHS in Slovenia, and subsequently 125 $\mathrm{SH}$ entrepreneurs.

The measuring instrument for the semi-structured in-depth interviews with $\mathrm{sH}$ entrepreneurs and $\mathrm{sH}$ Directors was a questionnaire, which consisted of these five questions:

1. What inspired you to start a hotel business?

2. What previous experience did you have in hospitality, hotel business, tourism or entrepreneurship/management?

3. (How) are you involved in the hotel business activities and in the everyday hotel tasks?

4. When did you start the $\mathrm{sH}$ business?

5. (How) are your family members involved into the hotel business?

By setting these questions, we intended to discover (1) The typology of SH entrepreneurs' motivation to start their business (whether they were $\mathrm{sH}$ entrepreneurs motivated by necessity or by opportunity); (2) The role of hotel owners in hotel management ( $\mathrm{sH}$ entrepreneurs as owner-managers or owner-supervisors); (3) The interviewees' experience as hotel entrepreneurs (new/nascent or experienced SH entrepreneurs); (4) The typology of hotel entrepreneurs according to their business goals (businessoriented or lifestyle sH entrepreneurs), and (5) The role of entrepreneur's family in hotel operations (whether we talk to a family or to a non-family sH entrepreneur). The results regarding the five indicated categories are described later on in the text.

The participants in this research were interviewed in their own setting by one of the authors. After the interview was completed, all sH entrepreneurs (yet not the sH directors) were asked to fill-in a short questionnaire - our aim was to determine the type of $\mathrm{sH}$ entrepreneur with regard to their business orientation: Whether they were (a) Business-oriented or (b) Lifestyle entrepreneurs (through sH entrepreneur's goals related to their $\mathrm{sH}$ ). Based on previous research in the hospitality industry, we put down ten statements. Five were related to economic goals, which are characteristic for economic/business oriented en- 
Table 1 Gender, Age and Level of Education of Interviewees

\begin{tabular}{|c|c|c|c|c|c|}
\hline \multirow[t]{2}{*}{ Category } & \multirow[t]{2}{*}{ Subcategory } & \multicolumn{2}{|c|}{ sH entrepreneurs } & \multicolumn{2}{|c|}{ sH directors } \\
\hline & & $f$ & $f \%$ & $f$ & $f \%$ \\
\hline \multirow[t]{2}{*}{ Gender } & Male & 29 & 58.0 & 3 & 25.5 \\
\hline & Female & 21 & 42.0 & 9 & 74.5 \\
\hline \multirow[t]{5}{*}{ Age } & Less than 30 years & 5 & 10.0 & o & 0.0 \\
\hline & $30-39$ & 15 & 30.0 & 9 & 75.0 \\
\hline & $40-49$ & 22 & 44.0 & 2 & 16.7 \\
\hline & $50-59$ & 6 & 12.0 & 1 & 8.3 \\
\hline & More than 60 years & 2 & 4.0 & 0 & 0.00 \\
\hline \multirow[t]{4}{*}{ Level of education } & Secondary & 21 & 42.0 & 4 & $33 \cdot 3$ \\
\hline & College & 9 & 18.0 & 3 & 25.0 \\
\hline & University (Applied Sc.) & 19 & 38.0 & 5 & 41.7 \\
\hline & $\mathrm{MA} / \mathrm{PhD}$ & 1 & 2.0 & o & 00.0 \\
\hline
\end{tabular}

Notes Note: $f$ - frequency $(n=62), f \%$ - percentage.

trepreneurs, and five were related to non-economic goals, thus, characteristic for lifestyle entrepreneurs. The respondents expressed their opinions on a scale from one (not important at all) to five (of key importance).

We interviewed in total $62 \mathrm{SH}$ entrepreneurs and $\mathrm{SH}$ directors (49.6\% response rate). Qualitative data collected during the interviews were analysed through interpretation, by defining patterns, by comparing selected features, and by indicating differences between responses; some data were quantified. While analysing the data, we took into account the theoretical perspectives of the studied phenomena, which had been presented in the findings of existing studies on entrepreneurship in general, as well as on entrepreneurship in the hospitality sector. We collected 44 questionnaires (35.2\% response rate). The numerical data from questionnaires was processed by using multiple statistical methods: Factor analysis, hierarchical classification into groups by defining the Euclidean distance, and by Ward's method of hierarchical cluster analysis.

\section{Sample Description}

We interviewed $50 \mathrm{SH}$ entrepreneurs and $12 \mathrm{SH}$ managers. The structure of interviewees by gender is fairly uniform: 32 males and 30 females. The findings in existing literature show that successful entrepreneurs are around 40 years old (Tajnikar, 1997). Our interviewees were between $30-49$ years old: $\mathrm{SH}$ entrepreneurs were $40-49$ years old (44\%), whereas the sH Directors were, on average, ten years younger. More than half of the $\mathrm{sH}$ entrepreneurs and sH Directors had a college level of education or higher (Table 1).

\section{Small Hotel Entrepreneurs in Slovenia}

Results of the Field Research

\section{SH Entrepreneurs out of Necessity or out of Opportunity}

The division of entrepreneurs into the two mentioned groups is the most frequently used typology, often used in broad studies on entrepreneurship (e.g. the worldwide Global Entrepreneurship Monitor study). In Slovenia, entrepreneurs motivated by opportunity prevailed until 2011; from 2012 on, their share has been decreasing (Rebernik et al., 2015). According to the mentioned Global Entrepreneurship Monitor study, the share of entrepreneurs out of necessity amounted to $53 \%$ in Slovenia. In our sample, only three sH entrepreneurs started their $\mathrm{sH}$ business out of necessity (they were unemployed). Others entered their hotel business out of opportunity (Table 2 ).

\section{SH Entrepreneurs as Owner-Managers} or Owner-Supervisors

According to the international research of hospitality entrepreneurship, a typical representative of hos- 
Table 2 sH Entrepreneurs Motivated by Necessity or by Opportunity

\begin{tabular}{lrr}
\hline Category & $f$ & $f \%$ \\
\hline Opportunity & 3 & 4.8 \\
Necessity & 59 & 95.2 \\
\hline
\end{tabular}

Notes $f$-frequency $(n=62), f \%$ - percentage.

Table 3 Share of sH Entrepreneurs as Owner-Managers or Owner-Supervisors

\begin{tabular}{lcr}
\hline Category & $f$ & $f \%$ \\
\hline Owner-manager & 41 & 66.1 \\
Owner-supervisor & 21 & 33.9 \\
\hline
\end{tabular}

Notes $f$ - frequency $(n=62), f \%$ - percentage.

pitality entrepreneurs is an owner-manager (Getz et al., 2004; Lee-Ross \& Lashley, 2009); this is a person who owns/establishes a TSME and who manages it. The sample of Slovene sH entrepreneurs consisted of two-thirds of owner-managers (Table 3 ). They manage their sH directly, work in it, and form an important part of its internal environment. They often manage the hotel together with family members, especially if the $\mathrm{SH}$ is a family business. One-third of $\mathrm{sH}$ entrepreneurs in the sample were owner-supervisors; they direct the hotel business from outside. The operational work is carried out by a hired st Director. The majority of these sH entrepreneurs do not run only the hotel included into our research - they usually run other business(es) as well.

\section{Family or Non-Family SH Entrepreneurs}

According to the ownership structure, all sH in the cluster of TSMEs belong into the category of family businesses. The family typology of $\mathrm{sH}$ entrepreneurs was, therefore, determined according to the interviewee's opinion, whether they considered their sH to be a family business or not.

Family businesses are a frequent internal organisation practice in TSMEs (Getz et al., 2004). Among the participants in our sample, $71 \%$ considered their sH to be a family business. In most cases (except in four $\mathrm{sH}$ ), the premises were owner-managed (Table 4). Family businesses make up more than $60 \%$ of all companies in
Table 4 Family Typology of sHs

\begin{tabular}{lrr}
\hline Category & $f$ & $f \%$ \\
\hline Yes & 44 & 71.0 \\
No & 18 & 29.0 \\
\hline Notes $\quad f$ - frequency $(n=62), f \%$ - percentage. &
\end{tabular}

Table 5 Number of Years of sH Entrepreneurs in sHs

\begin{tabular}{lrr}
\hline Category & $f$ & $f \%$ \\
\hline Less than two years & 13 & 20.1 \\
2-5 years & 11 & 17.7 \\
6-10 years & 25 & 40.3 \\
11-20 years & 9 & 14.5 \\
More than 20 years & 4 & 6.4 \\
\hline Notes $f$ - frequency $(n=62), f \%$ - percentage. &
\end{tabular}

Europe (European Commission, n.d.). In the Slovene Hotel sector, as well as abroad, a strong correlation exists between the family typology of hotel entrepreneurship and the extent to which an entrepreneur participates in managerial and other hotel activities. Four sH entrepreneurs, who do not consider their $\mathrm{SH}$ a family business, believe that their involvement in $\mathrm{sH}$ is something they simply 'do as business as usual', thus as a job that enables them 'to make a living. Those four interviewees were not 'emotionally attached' to the sH.

\section{New/Nascent or Experienced SH Entrepreneurs}

We grouped the sH entrepreneurs into one of the two indicated clusters with regard to the duration of business activities in their sH. We could determine only $20 \%$ of $\mathrm{sH}$ entrepreneurs as being pure 'nascents' (having two years or less experience as $\mathrm{SH}$ entrepreneurs). All other $\mathrm{sH}$ entrepreneurs have already had certain business experience, slightly over $20 \%$ even more than ten years (Table 5 ).

This information indicates the entrepreneurs' attitude toward work, enthusiasm, their competence of being an SH entrepreneur, and the success of their businesses. The difference in business enthusiasm and in the approach how to run their businesses was detected in interviewed sH entrepreneurs: Nascent sH entrepreneurs were keen at having an $\mathrm{SH}$ and proud of their success. Despite the relatively unfavourable 
Table 6 Areas of Previous Experience of $\mathrm{sH}$ Entrepreneurs

\begin{tabular}{lrr}
\hline Category & $f$ & $f \%$ \\
\hline In hotel or tourism accommodation & 19 & 30.6 \\
In F \& B & 14 & 22.6 \\
In tourism & 6 & 9.7 \\
In entrepreneurship and/or management & 23 & 37.1 \\
\hline
\end{tabular}

Notes $f$-frequency $(n=62), f \%$ - percentage.

economic conditions in which they established their $\mathrm{sH}$, they remained optimistic, and believed that, with time, 'things would improve.' sH entrepreneurs with 'a longer mileage in $\mathrm{sH}$ ' are realistic about their experience in sHs. Over the years, they were able to surmount the difficulties caused by wrong business decisions they met during the planning and the beginning phase of their sHs.

Still regarding the $\mathrm{sH}$ entrepreneurs' experiences, we examined what kind of experiences the $\mathrm{sH}$ entrepreneurs had.

We divided their experience into professional experiences and entrepreneurial-managerial experiences. We defined the professional one as being an experience in the hospitality sector and tourism related activities, e.g.: (a) A hotel or other tourist accommodation (rooms, apartments etc.), (b) F\&B and (c) Tourism (organising excursions, gambling, events etc.).

More than $60 \%$ (39) of SH entrepreneurs in the sample started their entrepreneurial path in an $\mathrm{sH}$ with professional experience, half of them also with previous entrepreneurial experiences. Other sH entrepreneurs (23) started their SH as existing entrepreneurs or/and managers in different business fields: In the Construction sector (three), Real-estate (three), Electronics, Gambling, Metal production, Production of furniture, Metallurgy, Exhibition activities, Sports, Legal profession, Food Industry, etc. Three sH entrepreneurs opened their sHs with experience in financial management (Table 6).

We also found out that the majority of $\mathrm{sH}$ entrepreneurs with entrepreneurial-managerial experiences, also played the role of owner-supervisor or investor. Hotel activity has, thus, not been their only business activity.
Results of the Quantitative Research Business Oriented or Lifestyle SH Entrepreneurs

These two types of entrepreneurs were established in accordance with entrepreneurial business orientation by employing hierarchical classification into groups with Euclidean distance, and by Ward's method of hierarchical cluster analysis. Likert type scales were used for testing continuous variables, and factor analysis was used to investigate the validity of measurement. We also calculated the Cronbach $\alpha$ to investigate the measurement reliability (whereas values $>0.60$ are considered as indicators of sufficient reliability). Composite variables were calculated as the mean value of items measuring the same construct, and used in consecutive analysis.

Factor analysis was carried out using the method of main axis perpendicular to the rotation (high weights for a factor mean that statements correlate considerably with the factor, and that they measure the same construct). The number of factors was determined on the basis value of $\lambda>1$. The suitability of the factor analysis for the data was verified by using the KaiserMeyer-Olkin sample adequacy (which should be higher than 0.50), and the Bartlett test of sphericity to test whether the correlation matrix was an identity matrix (when $p \leq 0.05$ it can be concluded that there is a correlation between measured variables).

We also proved the validity and the reliability of the business-oriented SH entrepreneurs' measurement.

We tested five statements - they are shown in Table 7 - in order to measure the $\mathrm{SH}$ entrepreneurs' business orientation (results are displayed in the middle column). The first statement (about making high profit) was excluded from further analysis due to its low weighting factor $(<0.3)$. After its exclusion, the K мо value shows that the data were adequate for the factor analysis. The reliability of the measurement was low, yet above the minimum threshold (o.6) (Table 7). A combined variable was created as an average of the four remaining statements.

\section{Validity and Reliability of Measurement for Lifestyle Entrepreneurs}

Lifestyle entrepreneurship was measured with five statements, and we found out that factor weights were 
Table 7 Determining the Business-Oriented sH Entrepreneurs

\begin{tabular}{|c|c|c|c|}
\hline Category & Subcategory & (1) & (2) \\
\hline \multirow{2}{*}{$\begin{array}{l}\text { Data suitability } \\
\text { for factor analysis }\end{array}$} & KMO & 0.493 & 0.52 \\
\hline & Bartlett sphericity test & $\begin{array}{r}\chi^{2}=42.6 \\
d f=10 \\
p \leq 0.001\end{array}$ & $\begin{array}{r}\chi^{2}=37.2 \\
d f=6 \\
p \leq 0.001\end{array}$ \\
\hline \multirow{5}{*}{$\begin{array}{l}\text { Statements } \\
\text { (factor weights) }\end{array}$} & High profit creation from operations & 0.2 & \\
\hline & Purchase of equity investment for a high profit when sold & 0.8 & 0.8 \\
\hline & Taking the opportunity for investing capital assets & 0.8 & 0.8 \\
\hline & Further growth (expansion) of the enterprise in hotel activity & 0.5 & 0.4 \\
\hline & Synergy between hotel- and some other business activity & 0.4 & 0.4 \\
\hline \multirow{2}{*}{$\begin{array}{l}\text { Validity and the } \\
\text { reliability }\end{array}$} & Percentage of explained variance & 32.6 & 39.9 \\
\hline & Cronbach $\alpha$ & & 0.7 \\
\hline
\end{tabular}

Notes Column headings are as follows: (1) all statements, (2) limited number of statements.

Table 8 Determining the Lifestyle sh Entrepreneurs

\begin{tabular}{llr}
\hline Category & Subcategory & All statements \\
\hline Data suitability for factor analysis & KMO & $\chi^{2}=18.58, d f=10, p=0.046$ \\
\hline Statements (factor weights) & Bartlett sphericity test & 0.5 \\
& Pleasure with hotel work (job of 'my life') & 0.6 \\
& Moderate earnings (not to become rich) & 0.6 \\
& Creation/continuing family tradition & 0.4 \\
& Combining moderate work with quality personal life & 0.5 \\
\hline Validity and the reliability & Improved status (position) in the environment/community & 24.6 \\
& Percentage of explained variance & 0.6 \\
\hline
\end{tabular}

medium high: None of the statements had a high weight. The share of explained variance of variables with a common factor lay slightly lower (24.6\%). The reliability of the measurement was slightly above the minimum threshold (o.6) (Table 8).

A combined variable was created as an average of the five statements that reflect the extent to which an sH entrepreneur was a lifestyler.

We classified the answers with hierarchical classification in groups by using the Euclidean distance as a measure of similarity between units and Ward's method of clustering. Based on responses regarding the variables that measure either the lifestyle- or the business-orientated entrepreneurship, we identified two types of SH entrepreneurs: 17 lifestyle sH entrepreneurs and 27 business-oriented SH ntrepreneurs (Table 9).

\section{Conclusions}

Individuals that start the entrepreneurial process have to run their business in a certain social and economic system; they are challenged by their personal needs, wishes, motives, goals, experiences etc. In theory, most of these circumstances are considered to be suitable criteria for the classification of entrepreneurs (which type they belong to). Most commonly, we differentiate between the following types: Entrepreneurs motivated by necessity or opportunity; owner-managers or owner-supervisors; nascent or established/experienced entrepreneurs, and business-oriented or life- 
Table 9 Description of sH Entrepreneurial Types in Accordance with Their Business Orientation

\begin{tabular}{llll}
\hline Category & & $(1)$ & $(2)$ \\
\hline (1) Lifestyle SH & AM & 4.1 & 2.6 \\
entrepreneurs & SD & 0.7 & 0.8 \\
& $n$ & 17 & 17 \\
\hline (2) Business-oriented & AM & 3.2 & 3.7 \\
SH entrepreneurs & SD & 0.6 & 0.5 \\
& $n$ & 27 & 27 \\
\hline Total & AM & 3.5 & 3.3 \\
& SD & 0.7 & 0.8 \\
& $n$ & 44 & 44 \\
\hline
\end{tabular}

Notes A M - arithmetic mean, SD - standard deviation, $n-$ number of responses.

style entrepreneurs. Which type is prevailing differs from country to country, as well as from industry to industry. It depends on the general perception of entrepreneurship in each country, on countries' economic circumstances, as well as on particularities of individual industries etc.

With our research, we could gain insight into the typology of entrepreneurs in small hospitality enterprises in Slovenia. We investigated the types of entrepreneurs that are characteristic for the SH business in Slovenia, and compared the findings with result of similar studies abroad (where such data were available).

The results of this study show (1) That sH entrepreneurs in Slovenia entered the hospitality business predominantly looking for a prosperous business opportunity, not out of necessity. The percentage of the first type of entrepreneurs is significantly higher than in other industries in Slovenia, but similar to the hospitality business abroad. (2) However, there are less owner-managers in Slovenia's sH than in small hospitality businesses abroad. One of the reasons could be the fact that many sH entrepreneurs in Slovenia are involved in other business areas too, and not only in hospitality (like their colleagues abroad). (3) Less entrepreneurs in Slovenia consider their $\mathrm{sH}$ a family business than abroad, where family businesses in the small hospitality area prevail strongly. This finding raises an interesting question: Is this the consequence of a still evolving family business scene in Slovenia, after this tradition was cut and persecuted by the communist regime after the second world war? The finding (4) was rather unexpected: Among sH entrepreneurs, we found a high share of experienced business women/men, which is not usually the case in other studies on hospitality entrepreneurs. Even more: Most of them have had previous professional experiences (in hotel or other tourist accommodation, or in the F\& B sector, tourist agencies or similar), and the rest had at least previous managerial (if not both, managerial and entrepreneurial) experience. This finding was completely unlike the sH businesses abroad. However, our finding (5) showed that, in Slovenia, in accordance with common findings in existing studies, less than half of individuals start their entrepreneurial path in the industry they used to work in. Furthermore, the results of our research showed that $\mathrm{sH}$ entrepreneurs in Slovenia are not lifestyle entrepreneurs to the extent that we expected; their number was considerably lower than in similar studies conducted in the past.

\section{References}

Amit, R., \& Muller, E. (2013). 'Push' and 'pull' entrepreneurship. Journal of Small Business \& Entrepreneurship, 12(4), 64-8o.

Antončič, B., Hisrich, R. D., Petrin, T., \& Vahčič A. (2002). Podjetništvo. Ljubljana, Slovenia: GV založba.

Ateljević, J., \& Li, L. (2009). Tourism entrepreneurship concepts and issues. In J. Ateljević, \& J. Stephen (Ed.), Tourism and entrepreneurship: International perspectives (pp. 9-31). Oxford, England: Butterworth-Heinemann.

Barringer, B. R., \& Ireland, R. D. (2012). Entrepreneurship: successfully launching new ventures (4th ed.). Boston, MA: Pearson.

Baron, R., \& Ansley, M. D. (2006). Opportunity recognition as the detection of meaningful patterns: Evidence from comparison of novice and experienced entrepreneurs. Management Science, 52(9), 1331-1344.

Bredvold, R., \& Skalen, P. (2016). Lifestyle entrepreneurs and their identity construction: A study of the tourism industry. Tourism Management, 56, 96-105.

Cerović, Z. (2010). Hotelski menadžment (2nd ed.). Opatija, Croatia: Faculty for tourism and hospitality management of University in Rijeka.

Clarke, A., \& Chen, W. (2007). International hospitality man- 
agement: Concepts and cases. Oxford, England: Butterworth-Heinemann.

Dincer, M. A. M., Yildirim, M., \& Dil, E. (2011). Is there any linkage between entrepreneur typologies and strategy typologies. Procedia: Social and Behavioural Sciences, 24, 601-610.

Dunkelberg, W., Moore, C., Scott, J., \& Stull, W. (2013). Do entrepreneurial goals matter? Resource allocation in new owner-managed firms. Journal of Business Venturing, 38, 225-240.

Entrepreneurship in the EU and beyond (Flash в в Series \#283). (2010). Retrieved from http://ec.europa.eu/ commfrontoffice/publicopinion/flash/fl_283_en.pdf

Emami, A., \& Dimov, D., (2017). Degree of innovation and the entrepreneurs' intention to create value: A comparative study of experienced and novice entrepreneurs. Eurasian Business Review 7(2), 161-182.

European Commission. (N.d). Family business. Retrieved from https://ec.europa.eu/growth/smes/promoting -entrepreneurship/we-work-for/family-business_sl

Global Entrepreneurship Monitor. (2015). 2014 Global Report. London, England: Global Entrepreneurship Research Association.

Getz, D., \& Carlsen, J. (200o). Characteristics and goals of family and owner-operated business in the rural tourism and hospitality sectors. Tourism Management, 21, 547560.

Getz, D., Carlsen, J., \& Morrison, A. (2004). The family business in tourism and hospitality. Wallingford, England: CABI.

Getz, D., \& Nilsson, P. A. (2004). Responses of family business to extreme seasonality in demand: The case of Bornholm, Denmark. Tourism Management, 25, 17-30.

Glas, M. (200o). Podjetništvo - izziv za 21. stoletje. In M. Glas \& V. Pšeničny (Ed.), Podjetništvo - izziv za 21. stoletje (pp. 1-5). Ljubljana, Slovenia: Gea College.

Glas, M. (2002). Podjetništvo: izziv za spremembe. In S. Možina, R. Rozman, M. Glas, M. Tavčar, D. Pučko, J. Kralj, Š. Ivanko, B. Lipičnik, J. Gričar, M. Tekavčič, V. Dimovski, \& B. Kovač (Eds.), Management: nova znanja za uspeh (pp. 96-132). Radovljica, Slovenia: Didakta.

Hall, C. M., \& Rusher, K. (2004). Risky lifestylers? Entrepreneurial characteristics of the New Zealand bed and breakfast sector. In R. Thomas (Ed.), Small firms in tourism: International perspectives (pp. 83-97). Oxford, England: Elsevier.

Hisrich, R. D., Peters, M. P., \& Shepherd, D. A. (2010). Entrepreneurship (8th ed.). New York, NY: McGraw-Hill Irwin.
Kuratko, D. F., \& Fodgetts, R. M. (1998). Entrepreneurship: A contemporary approach. Fort Worth, Tx: Dryden Press.

Lebe, S. S., \& Milfelner, B. (2006). Innovative organisation approach to sustainable tourism development in rural areas. Kybernetes, 35(7/8), 1136-1146.

Lee-Ross, D., \& Lashley, C. (2009). Entrepreneurship and small business management in the hospitality industry. Oxford, England: Butterworth-Heinemann.

Medlik, S., \& Ingram, H. (200o). The business of hotels (4th ed.). Oxford, England: Butterworth-Heinemann.

Minarcine, S., \& Shaw, C. (2016). Motivations for entrepreneurship. International Journal of the Academic Business World, 10(2), 47-56.

Morrison, A. (2001). Entrepreneurs transcend time: A biographical analysis. Management Decision, 39(9), 784791.

Page, S. J., \& Connell, J. (2014). Tourism: A modern synthesis (4th ed.). Andover, England: Cengage Learning.

Peltier, J. W., Schibrowsky, J. A., \& Zhao, Y. (2009). Understanding the antecedents to the adoption of CRM technology by small retailers. International Small Business Journal, 27(3), 307-336.

Peters, M., Frehse, J., \& Buhalis, D. (2009). The importance of lifestyle entrepreneurship: A conceptual study of tourism industry. Pasos, Revista de Turismo y Patrimonio Cultura, 7(2), 393-405.

Presenza, A., Yucele, M., \& Camillo, A. (2015). Passion before profit in hospitaltiy ventures: Some thoughts on lifestyle entrepreneurs and the case of 'Albergo Diffuso.' Sinergie: Italian Journal of Management, 34(99), 221-239.

Rebernik, M. (2008). Ekonomika podjetja (4th ed.). Ljubljana, Slovenia: Gv založba.

Rebernik, M., Tominc, P., Crnogaj, K., Širec, K., Bradač, B., \& Rus, M. (2015). Pomanjkanje vitalnosti slovenskega podjetništva: GEM Slovenija 2014. Maribor, Slovenija: Univerza v Mariboru.

Rebernik, M., Tominc, P., Glas, M., \& Pšeničny, V. (2004). Global Entrepreneurship Monitor 2002: The Slovenian report: The winding road to entrepreneurial society. Maribor, Slovenia: University of Maribor.

Randolf, R. V., Li, Z., \& Daspit, J. J. (2017). Toward a typology of firm corporate entrepreneurship. Journal of Small Business Management, 55(4), 530-546.

Randerson, K., Bettinelli, C., Fayolle, A., \& Anderson, A. (2015). Family entrepreneurship as a field of research: Exploring its contours and contents. Journal of Family Business Strategy, 6(3), 143-154.

Shaw, G., \& Williams, A. M. (2004). From lifestyle consumption to lifestyle production: Changing patterns of 
tourism entrepreneurship. In R. Thomas (Ed.), Small firms in tourism: International perspectives (pp. 100-113). Oxford, England: Elsevier.

Smith, N. R., \& Miner, J. B. (1983). Type of entrepreneur, type of firm, and managerial motivation: Implications for organizational life cycle theory. Strategic Management Journal, 4, 325-340.

Sun, X., \& Xu, H. (2017). Lifestyle tourism entrepreneurs' mobility motivations: A case study on Dali and Lijiang, China. Tourism Management perspectives, 24, 64-71.
Tajnikar, M. (1997). Tvegano poslovodenje: knjiga o gazelah in rastočih poslih. Ljubljana, Slovenia: Gea College.

Velu, C., \& Jacob, A. (2016). Business model innovation and owner-managers: The moderating role of competition. $R \& D$ Management, 46(3), 451-463.
This paper is published under the terms of the Attribution- NonCommercial-NoDerivatives 4.0 International (CC B Y-NC-ND 4.0) License. 